\title{
Roszczenie o zapłatę godziwej rekompensaty za korzystanie $z$ utworu osieroconego
}

\author{
Claim for fair compensation for the use of an orphan work \\ Требование справедливой компенсации за использование сиротского \\ произведения
}

\author{
GRZEGORZ TYLEC \\ Dr hab., prof. Katolickiego Uniwersytetu Lubelskiego Jana Pawła II \\ e-mail: grzegorztylec@kul.lublin.pl, https://orcid.org/0000-0003-2016-4523
}

\begin{abstract}
Streszczenie: Art. $35^{8}$ ust. 5 ustawy o prawie autorskim i prawach pokrewnych, wprowadzony ustawą z dnia 11 września 2015 r. o zmianie ustawy o prawie autorskim i prawach pokrewnych oraz ustawy o grach hazardowych, implementującą do polskiego porządku prawnego dyrektywę Parlamentu Europejskiego i Rady 2012/28/UE z dnia 25 października 2012 r. w sprawie niektórych dozwolonych sposobów korzystania z utworów osieroconych, wykreował nieznane polskiemu prawu cywilnemu roszczenie o „zapłatę godziwej rekompensaty za korzystanie z utworu". Podmiotem, który może podnieść to roszczenie, jest uprawniony z tytułu praw autorskich, którego utwór był eksploatowany w ramach konstrukcji dozwolonego użytku utworów osieroconych (art. $35^{5}-35^{9}$ ustawy o prawie autorskim i prawach pokrewnych). W artykule poddano analizie treść roszczenia z art. $35^{8}$ ust. 5 ustawy o prawie autorskim i prawach pokrewnych. W poszukiwaniu odpowiedzi na pytanie, w jaki sposób powinna być określona wartość tego roszczenia, zaprezentowane zostało orzecznictwo Trybunału Sprawiedliwości Unii Europejskiej, które dokonało jego interpretacji na gruncie dyrektywy 2001/29/ WE Parlamentu Europejskiego i Rady z dnia 22 maja 2001 r. w sprawie harmonizacji niektórych aspektów praw autorskich i pokrewnych w społeczeństwie informacyjnym. W konkluzji zaproponowany został sposób ustalania wielkości roszczenia o zapłatę godziwej rekompensaty za korzystanie z utworu.
\end{abstract}

Słowa kluczowe: prawo autorskie, utwór osierocony, godziwa rekompensata, roszczenie

Summary: Article $35^{8}$ paragraph 5 of the Polish Copyright and Related Rights Act introduced by the Act of 11 September 2015, amending the Copyright and Related Rights Act and the Gambling Act, implementing the Directive of the European Parliament and the Council 2012/28/UE to the Polish legal order uses of orphan works, created a claim unknown to Polish civil law for the "payment of fair compensation for the use of the work". The entity that may raise this claim is the copyright holder, whose work was exploited as orphan works (articles $35-35^{9}$ of the Copyright and Related Rights Act). In this article, the claim for payment of fair compensation for the use of the work was analyzed. Seeking an answer to the question of how to estimate the value of this claim was presented in the judgment of the Court of Justice of the European Union of 21 October 2010 in the SGAE v Padawan case. The conclusion of the article proposes a method of determining the value of the claim, and the payment of fair compensation for the use of the work.

Key words: copyright, orphan work, fair compensation, claim

Резюме: Статья 358 (5) Закона об авторском праве и смежных правах, введенная Законом от 11 сентября 2015 года о внесении изменений в Закон об авторском праве и смежных правах и Закон об азартных играх, имплементируя в польскую правовую систему Директиву 2012/28/EU Европейского парламента и Совета от 25 октября 2012 года об определенных разрешенных видах использования сиротских произведений, создала требование о «выплате справедливой компенсации за использование произведения», неизвестное польскому гражданскому праву. Субъектом, который может требовать возмещения, является владелец авторских прав, чье произведение использовалось в рамках разрешенного 
использования сиротских произведений (ст. 355-359 Закона об авторском праве и смежных правах). В статье анализируется содержание требования по статье $35^{8}$ (5) Закона об авторском праве и смежных правах. В поисках ответа на вопрос, как должна определяться сумма этого требования, была представлена судебная практика Суда Европейского Союза, который истолковал его на основании Директивы 2001/29/ЕС Европейского парламента и Совета Европейского Союза от 22 мая 2001 года о гармонизации некоторых аспектов авторского права и смежных прав в информационном обществе. В заключение предлагается метод определения объема требования выплаты справедливой компенсации за использование произведения.

Ключевые слова: авторское право, сиротское произведение, справедливая компенсация, требование

\section{Wstęp}

Ustawą z dnia 11 września 2015 r. o zmianie ustawy o prawie autorskim i prawach pokrewnych oraz ustawy o grach hazardowych ${ }^{1}$ dokonano implementacji dyrektywy Parlamentu Europejskiego i Rady 2012/28/UE z dnia 25 października 2012 r. w sprawie niektórych dozwolonych sposobów korzystania z utworów osieroconych $^{2}$, która uregulowała $\mathrm{w}$ przepisach polskiego prawa autorskiego ${ }^{3} \mathrm{za}-$ gadnienie dozwolonego użytku utworów osieroconych (art. $\left.35^{5}-35^{9}\right)$. W rezultacie do polskiej ustawy o prawie autorskim i prawach pokrewnych wprowadzony został m.in. art. $35^{8}$ ust. 5, który wykreował nieznane dotychczas polskiemu prawu cywilnemu roszczenie o zapłatę godziwej rekompensaty za korzystanie z utworu. Celem niniejszego artykułu jest odpowiedź na pytanie, jakimi kryteriami powinien kierować się sąd zasądzający roszczenie pieniężnie wynikające $\mathrm{z}$ art. $35^{8}$ ust. 5 ustawy o prawie autorskim. Czy pod pojęciem „zapłata godziwej rekompensaty za korzystanie z utworu" należy rozumieć równowartość wynagrodzenia autorskiego, odszkodowania, zadośćuczynienia czy wszystkie te pojęcia? Czy roszczenie $\mathrm{z}$ art. $35^{8}$ ust. 5 powinno być interpretowane przez pryzmat przesłanek opisanych $\mathrm{w}$ art. 79 ustawy o prawie autorskim? Aby udzielić odpowiedzi na powyższe pytania badawcze, postawiono dwie tezy, zgodnie z którymi:

1) Pojęcie "godziwego wynagrodzenia”, występujące w tekście dyrektywy 2012/28/UE, powinno być rozumiane w taki sam sposób jak to samo pojęcie użyte w treści dyrektywy 2001/29/WE Parlamentu Europejskiego i Rady

\footnotetext{
Dz. U. z 2015 r. poz. 1639.

Dz. Urz. UE L 299 z 27.10.2012 (dalej: dyrektywa 2012/28/UE).

Ustawa z dnia 4 lutego 1994 r. o prawie autorskim i prawach pokrewnych, tekst jednolity: Dz. U. z 2019 r. poz. 1231 z późn. zm.
} 
z dnia 22 maja 2001 r. w sprawie harmonizacji niektórych aspektów praw autorskich i pokrewnych w społeczeństwie informacyjnym ${ }^{4}$;

2) Do roszczenia o zapłatę godziwego wynagrodzenia wynikającego z polskiej ustawy o prawie autorskim i prawach pokrewnych znajdzie zastosowanie interpretacja pojęcia "godziwego wynagrodzenia”, której dokonał Trybunał Sprawiedliwości Unii Europejskiej w sprawie Padawan SL przeciwko SGAE ${ }^{5}$, na gruncie art. 5 ust. 2 lit. b dyrektywy 2001/29/WE. Istotą postawionej tezy jest założenie, że uwagi poczynione przez TSUE we wskazanym orzeczeniu powinny stać się podstawą interpretacji art. $35^{8}$ ust. 5 polskiej ustawy o prawie autorskim i prawach pokrewnych ${ }^{6}$.

Warto odnotować, że pojęcie „godziwej rekompensaty” zostało użyte przez prawodawcę europejskiego w treści dyrektywy 2001/29/WE w kontekście rekompensaty za realizowaną $\mathrm{w}$ ramach dozwolonego użytku osobistego reprografię. Pojęcie to pojawia się także w dyrektywie Parlamentu Europejskiego i Rady (UE) 2019/790 z dnia 17 kwietnia 2019 r. w sprawie prawa autorskiego i praw pokrewnych na jednolitym rynku cyfrowym ${ }^{7}$, m.in. w art. 5 ust. 4 dotyczącym wyjątku w zakresie cyfrowego korzystania $\mathrm{z}$ utworów i innych przedmiotów objętych ochroną $\mathrm{w}$ celu zilustrowania $w$ ramach nauczania oraz $w$ art. 16 dającym wydawcy prawo do bycia uprawnionym do udziału w rekompensacie za korzystanie $\mathrm{z}$ utworu, które miało miejsce na podstawie wyjątku lub ograniczenia. Nie jest zatem wykluczone, że implementacja do polskiego porządku prawnego dyrektywy 2019/790, która powinna nastąpić w najbliższych miesiącach, wprowadzi do tego aktu prawnego kolejne roszczenia o zapłatę godziwej rekompensaty. Wskazana okoliczność powoduje, że analiza natury prawnej roszczenia o zapłatę tzw. godziwej rekompensaty jest tym bardziej uzasadniona.

4 Dz. Urz. UE WE L 167/10 z 22.06.2001 (dalej: dyrektywa 2001/29/WE).

5 Wyrok TSUE z dnia 21 października 2010 r. w sprawie C-467/08, Padawan SL przeciwko Sociedad General de Autores y Editores de España (SGAE), http://curia.europa.eu/juris/document/document .jsf?docid=83635\&doclang=PL, wszedł w życie z dniem 4 listopada 2019 r. [dostęp: 21.05 .2020 r.].

6 W wyroku TSUE z dnia 21 października 2010 r. w sprawie C-467/08 stwierdzono, że pojęcie godziwej rekompensaty „stanowi autonomiczne pojęcie prawa Unii, które należy interpretować w sposób jednolity we wszystkich państwach członkowskich, w których wprowadzono wyjątek kopii na użytek prywatny".

7 Dyrektywa Parlamentu Europejskiego i Rady (UE) 2019/790 z dnia 17 kwietnia 2019 r. w sprawie prawa autorskiego i praw pokrewnych na jednolitym rynku cyfrowym oraz zmiany dyrektyw 96/9/ WE i 2001/29/WE, Dz. Urz. UE L 130/92 z 17.05.2019 (dalej: dyrektywa 2019/790). 


\section{Dozwolony użytek utworów osieroconych}

Przepisy dotyczące użytku utworów osieroconych znalazły się w rozdziale 3 ustawy o prawie autorskim, zatytułowanym Treść prawa autorskiego, oraz rozdziale 5, zatytułowanym Dozwolony użytek utworów osieroconych. Przez utwory osierocone w myśl art. $35^{5}$ ust. 1 ustawy o prawie autorskim należy rozumieć:

1) utwory opublikowane w książkach, dziennikach, czasopismach lub innych formach publikacji drukiem;

2) utwory audiowizualne, a także utwory zamówione lub włączone do utworów audiowizualnych lub utrwalone na wideogramach, w zakresie korzystania $\mathrm{z}$ utworu audiowizualnego lub wideogramu jako całości;

3) utwory utrwalone na fonogramach:

- znajdujące się w zbiorach podmiotów takich jak archiwa, instytucje oświatowe, uczelnie, instytuty badawcze, biblioteki i muzea, a także instytucje kultury, których statutowym zadaniem jest gromadzenie, ochrona i upowszechnianie zbiorów dziedzictwa filmowego lub fonograficznego, oraz publiczne organizacje radiowe i telewizyjne;

- jeżeli uprawnieni, którym przysługują autorskie prawa majątkowe do tych utworów w zakresie pól eksploatacji wymienionych w ust. 2 art. $35^{5}$ ustawy o prawie autorskim, nie zostali ustaleni lub odnalezieni pomimo przeprowadzenia poszukiwań, o których mowa w art. $35^{6}$ ustawy o prawie autorskim ${ }^{8}$.

$\mathrm{Z}$ regulacji tej wynika, że po spełnieniu określonych wymogów (m.in. po przeprowadzeniu tzw. starannych poszukiwań) podmioty uprawnione $e^{9}$ mogą korzystać $\mathrm{z}$ utworów osieroconych w sposób opisany w art. $35^{5}$ ust. 2 ustawy o prawie autorskim, który może polegać na:

8 Na temat pojęcia „utwór osierocony” zob. S. Stanisławska-Kloc, Utwory „osierocone”, Zeszyty Naukowe Uniwersytetu Jagiellońskiego. Prace z Prawa Własności Intelektualnej 2007, nr 4, s. 455; A. Vetulani, Dzieła osierocone - w poszukiwaniu europejskiego rozwiązania, Zeszyty Naukowe Uniwersytetu Jagiellońskiego. Prace z Prawa Własności Intelektualnej 2009, nr 1, s. 27; A. Niewęgłowski, Dyrektywa w sprawie dzieł osieroconych i jej znaczenie dla polskiego prawa autorskiego, Transformacje Prawa Prywatnego 2013, nr 3, s. 78.

9 Jako podmioty uprawnione do korzystania z utworów osieroconych przepis art. 35 (5) ust. 2 ustawy o prawie autorskim wylicza: archiwa, instytucje oświatowe, uczelnie, instytuty badawcze prowadzące działalność, o której mowa w art. 2 ust. 3 ustawy z dnia 30 kwietnia 2010 r. o instytutach badawczych, instytuty naukowe Polskiej Akademii Nauk prowadzące działalność, o której mowa w art. 50 ust. 4 ustawy z dnia 30 kwietnia 2010 r. o Polskiej Akademii Nauk, biblioteki i muzea, a także instytucje kultury, których statutowym zadaniem jest gromadzenie, ochrona i upowszechnianie zbiorów dziedzictwa filmowego lub fonograficznego, oraz publiczne organizacje radiowe i telewizyjne. 
a) zwielokrotnianiu utworów osieroconych, które były opublikowane, a w przypadku braku publikacji - nadane po raz pierwszy na terytorium Unii Europejskiej lub Europejskiego Obszaru Gospodarczego oraz

b) udostępnianiu publicznym utworów osieroconych w taki sposób, aby każdy mógł mieć do nich dostęp w miejscu i czasie przez siebie wybranym.

Ustawa zastrzega, że przedstawiony wyżej zakres korzystania z utworów osieroconych może mieć miejsce jedynie w celu realizacji służących interesowi publicznemu statutowych zadań podmiotów, które zostały wskazane jako uprawnione do eksploatacji dzieł osieroconych, a w szczególności zachowania, odnawiania i udostępniania w celach kulturalnych i edukacyjnych utworów znajdujących się w ich zbiorach. Podmioty te mogą uzyskiwać przychody z takiego korzystania, o ile zostaną one przeznaczone na pokrycie bezpośrednich kosztów digitalizacji i publicznego udostępniania utworów osieroconych (art. $35^{5}$ ust. 3 ustawy o prawie autorskim).

Jak wynika z przytoczonej treści regulacji prawnej, eksploatacja dzieł osieroconych może odbywać się bez wiedzy i zgody podmiotów uprawnionych. Istotą pojęcia „utwór osierocony” jest bowiem to, że jest to utwór, co do którego nie ma informacji na temat jego twórcy lub podmiot do niego uprawniony nie został odnaleziony. Po przeprowadzeniu starannych poszukiwań zakończonych negatywnie i rozpoczęciu korzystania z utworu osieroconego może dojść do sytuacji, w której nastąpi ustalenie podmiotu uprawnionego $\mathrm{z}$ tytułu praw autorskich lub odnalezienie go $^{10}$. Możliwa jest także sytuacja, w której podmiot uprawniony poweźmie informację o eksploatacji jego dzieła w ramach konstrukcji dozwolonego użytku utworów osieroconych. W powyższych przypadkach przepisy ustawy umożliwiają podmiotom uprawnionym domaganie się zaprzestania korzystania $\mathrm{z}$ utworów osieroconych oraz dodatkowo przyznają im prawo domagania się zapłaty godziwej rekompensaty za korzystanie z ich utworów (art. $35^{8}$ ust. 5 ustawy o prawie autorskim). Ani w przepisach dyrektywy 2012/28/UE, ani w polskiej ustawie nie wskazano expressis verbis chwili, z jaką następuje utrata statusu utworu osieroconego.

10 Warto zauważyć, że w sytuacji gdy dojdzie do ustalenia przez podmiot eksploatujący dzieło osierocone autora tego dzieła lub odnalezienia podmiotów uprawnionych do tego utworu, podmioty eksploatujące taki utwór osierocony nie mają obowiązku zaprzestać korzystania z tego utworu i zwrócić się o zawarcie stosownej umowy. Formalnie rzecz ujmując, mogą kontynuować korzystanie do momentu, w którym podmiot uprawniony, realizując swe uprawnienie $\mathrm{z}$ art. $35^{8}$ ust. 1 ustawy Prawo autorskie, nie wystąpi o stwierdzenie wygaśnięcia statusu utworu osieroconego. Powyższe rozwiązanie należy ocenić krytycznie. Brak jasno wyartykułowanego obowiązku w postaci zaprzestania korzystania po odnalezieniu podmiotu uprawnionego do dzieła osieroconego może skutkować zbędnymi procesami sądowymi o zapłatę godziwej rekompensaty za korzystanie z utworu osieroconego. 
W piśmiennictwie precyzuje się natomiast, że momentem tym jest data wykreślenia utworu $\mathrm{z}$ rejestru utworów osieroconych ${ }^{11}$.

Treść oraz charakter prawny wprowadzonego do ustawy nowego roszczenia o zapłatę godziwej rekompensaty za korzystanie z utworu może budzić wątpliwości interpretacyjne $\mathrm{z}$ uwagi na fakt, iż roszczenie tego rodzaju nie występuje $\mathrm{w}$ żadnym innym przepisie ustawy o prawie autorskim $\mathrm{i}$, jak się wydaje, nie występuje także $\mathrm{w}$ żadnej innej ustawie z zakresu prawa prywatnego. Wprowadzone do tekstu polskiej ustawy o prawie autorskim roszczenia „o zapłatę godziwej rekompensaty” jest dosłownym przeniesieniem treści art. 6 ust 5 dyrektywy 2012/28/UE, gdzie stwierdzono, że „państwa członkowskie zapewniają podmiotom uprawnionym, które dokonały unieważnienia statusu utworów lub innych przedmiotów objętych ochroną jako utworów osieroconych, godziwą rekompensatę za korzystanie [...]"12.

Zasadnicze wątpliwości może rodzić kwestia sposobów ustalania wysokości tegoż roszczenia oraz jego relacja do innych przewidzianych przepisami ustawy roszczeń (m.in. roszczeń opisanych w art. 79 ustawy o prawie autorskim). Zagadnienia te staną się przedmiotem analiz dalszej części artykułu.

11 J. Barta, R. Markiewicz, Prawo autorskie i prawa pokrewne. Przepisy z wprowadzeniem, Warszawa 2017, s. 136; podobnie J. Sieńczyło-Chlabicz, Nabycie i utrata statusu utworu osieroconego - uwagi de lege lata i de lege ferenda, w: Experientia docet. Księga jubileuszowa ofiarowana Pani Profesor Elżbiecie Traple, red. P. Kostański, P. Podrecki, T. Targosz, Warszawa 2017, s. 348; P.F. Piesiewicz, Godziwa rekompensata $i$ jej dochodzenie $w$ odniesieniu do dzieł osieroconych (art. 358 ust. 5 ustawy o prawie autorskim i prawach pokrewnych), Zeszyty Naukowe Uniwersytetu Jagiellońskiego 2018, nr 3, s. 36.

12 W pkt 18 preambuły dyrektywy 2012/28/UE wskazano, że: „Podmioty uprawnione powinny mieć możliwość unieważnienia statusu utworu osieroconego w przypadku zgłoszenia przez nie praw do swoich utworów lub innych przedmiotów objętych ochroną. Podmioty uprawnione, które unieważniają status utworu lub innego przedmiotu objętego ochroną jako utworu osieroconego, powinny otrzymać godziwą rekompensatę za korzystanie z ich utworów lub innych przedmiotów objętych ochroną zgodnie z niniejszą dyrektywą, której wysokość ustalana jest przez państwo członkowskie, w którym siedzibę ma organizacja korzystająca z danego utworu osieroconego. Państwa członkowskie powinny mieć swobodę określenia okoliczności, w których ma miejsce wypłata takiej rekompensaty, w tym terminu zapłaty należnej kwoty. Do celów określania możliwego poziomu godziwej rekompensaty trzeba należycie uwzględnić, między innymi, cele państw członkowskich związane z promowaniem kultury, niekomercyjny charakter korzystania z utworu przez przedmiotowe organizacje, którego celem jest realizacja zadań leżących $\mathrm{w}$ interesie publicznym, takich jak promowanie nauki i rozpowszechnianie kultury, oraz ewentualne szkody wyrządzone podmiotom uprawnionym". 
2. Pojęcie "godziwej rekompensaty" za użytek reprograficzny na gruncie dyrektywy 2001/29/WE Parlamentu Europejskiego i Rady z dnia 22 maja 2001 r. w sprawie harmonizacji niektórych aspektów praw autorskich i pokrewnych w społeczeństwie informacyjnym

W związku z tym, że pojęcie „godziwej rekompensaty” użyte w treści dyrektywy 2001/29/WE było przedmiotem analiz TSUE, dalsze rozważania warto rozpocząć od przedstawienia kontekstu, w jakim zostało ono użyte na gruncie dyrektywy 2001/29/WE. Zapewne kontekst ten okaże się istotny przy interpretacji art. $35^{8}$ ust. 5 ustawy o prawie autorskim.

W art. 2 dyrektywy 2001/29/WE zagwarantowano podmiotom praw autorskich i pokrewnych wyłączne prawo do zezwalania lub zabraniania bezpośredniego lub pośredniego, tymczasowego lub stałego zwielokrotniania utworu. W art. 5 ust. 2 lit. b dyrektywy przewidziano jednak wyjątki od wskazanej w art. 2 zasady ogólnej i stwierdzono, że państwa członkowskie mogą wprowadzić wyjątki lub ograniczenia w odniesieniu do prawa do zwielokrotniania obejmujące zwielokrotnianie na dowolnych nośnikach przez osobę fizyczną do prywatnego użytku i do celów „ani bezpośrednio, ani pośrednio handlowych, pod warunkiem, że podmioty praw autorskich otrzymają godziwą rekompensatę, uwzględniającą zastosowanie lub niezastosowanie środków technologicznych w odniesieniu do utworów lub przedmiotów objętych ochroną"13.

Wskazane regulacje prawne zawarte w dyrektywie 2001/29/WE zostały implementowane do polskiej ustawy o prawie autorskim i prawach pokrewnych. Celem wprowadzonych na podstawie tej dyrektywy przepisów była rekompensata strat majątkowych, doznawanych przez podmioty uprawnione $\mathrm{z}$ tytułu praw autorskich z powodu dokonywanego zgodnie z ustawą dozwolonego użytku osobistego utworów. Regulacje te są zawarte m.in. w treści art. 20 oraz $20^{1}$ ustawy o prawach autorskich oraz rozporządzeniach wykonawczych wydanych do tych przepisów (private copying levies $)^{14}$.

13 Por. D. Sokołowska, Prawo twórcy do wynagrodzenia w prawie autorskim, Poznań 2013, s. 326.

14 Por. szerzej taż, Opłaty reprograficzne, Warszawa 2014, s. 10 i nn.; M. Czajkowska-Dąbrowska, Opłaty reprograficzne - osobliwości konstrukcji, dylematy praktyki, w: Studia i analizy Sądu Najwyższego, red. K. Ślebzak, t. 4, Warszawa 2012, s. 153-154; M. Gołda-Sobczak, Opłaty reprograficzne w polskim prawie autorskim jako forma zarządzania kultura, Zarządzanie w Kulturze 2014, t. 15, nr 2, s. 135; J. Błeszyński, Podział opłat od producentów i importerów urządzeń kopiujących, Przegląd Ustawodawstwa Gospodarczego 2001, nr 12, s. 2; J. Szczotka, w: Prawo autorskie i prawa pokrewne. Zarys wykładu, red. M. Poźniak-Niedzielska, J. Szczotka, M. Mozgawa, Bydgoszcz 2006, s. 72. 
Warto zauważyć, że obowiązujące w Polsce regulacje prawne (art. 20 oraz $20^{1}$ ustawy o prawie autorskim) mają realizować wskazany w dyrektywie cel, którym jest zapewnienie uprawnionym podmiotom godziwej rekompensaty za realizowane w ramach dozwolonego użytku korzystanie z utworów. M. Kępiński i B. Kleban stwierdzili, iż wskazane przepisy „mają stanowić swego rodzaju wynagrodzenie za umniejszanie liczby kopii nabywanych egzemplarzy utworów i innych przedmiotów ochrony skutkiem ich zwielokrotnienia dla użytku osobistego"15. Uznano, że skoro nie sposób ustalić, które konkretnie utwory i jak często były eksploatowane w ramach użytku prywatnego, to opłatą obciążyć należy wszystkie podmioty korzystające $z$ utworów ${ }^{16}$.

Rzeczone przepisy (art. 20 oraz $20^{1}$ ustawy o prawie autorskim) scharakteryzowane zostały w polskim piśmiennictwie prawniczym jako kreujące roszczenia o charakterze cywilnoprawnym, które nie są postaciami odpowiedzialności za szkodę i nie pozostają w związku przyczynowym z czyimkolwiek uszczerbkiem. Jak wskazał J. Błeszyński, „roszczenie to ma charakter szczególny i w szczególności nie jest związane z konkretnym aktem eksploatacji utworu"17. Opisywane roszczenia powstają całkowicie niezależnie od woli stron stosunku prawnego, są one konsekwencją zrealizowania stanu faktycznego opisanego w treści ustawy, a dotyczącego produkcji i importu czystych nośników i urządzeń kopiujących oraz zawodowo dokonywanej działalność reprograficznej. Cechą charakterystyczną polskiej konstrukcji opłat reprograficznych wynikających z art. 20 oraz $20^{1}$ ustawy o prawie autorskim, mających gwarantować nałożony przez prawodawcę europejskiego obowiązek zapewnienia godziwej rekompensaty, jest to, że:

- z uwagi na to, że nie da się precyzyjnie wskazać kto, ile razy i w jakich okolicznościach korzystał z utworów, godziwa rekompensata wypłacana twórcom będzie zawsze miała charakter szacunkowy;

- do wypłaty wynagrodzenia nie jest wymagane wykazanie przez uprawnionego, że doznał konkretnej szkody, która pozostaje w adekwatnym związku przyczynowym z działaniem podmiotu eksploatującego utwór.

W pkt 35 preambuły dyrektywy 2001/29/WE zaznaczono, że: „W niektórych przypadkach dotyczących wyjątków lub ograniczeń podmioty praw autorskich

15 M. Kępiński i B. Kleban stwierdzili, że wskazane przepisy „mają stanowić swego rodzaju wynagrodzenie za umniejszanie liczby kopii nabywanych egzemplarzy utworów i innych przedmiotów ochrony skutkiem ich zwielokrotnienia dla użytku osobistego", por. tychże, w: System Prawa Prywatnego, t. 13. Prawo autorskie, red. J. Barta, wyd. 3, Warszawa 2013, s. 728.

16 Por. M. Czajkowska-Dąbrowska, Opłaty reprograficzne - osobliwości konstrukcji, dylematy praktyki, w: Studia i Analizy Sądu Najwyższego, t. 4, red. K. Ślebzak, Warszawa 2012, s. 153 i nn.

17 J. Błeszyński, Glosa do postanowienia SA z dnia 24 lutego 2009 r., I ACa 99/09, Przegląd Ustawodawstwa Gospodarczego 2009, nr 7, s. 14 i nn. 
powinny otrzymać godziwą rekompensatę jako wynagrodzenie za korzystanie z ich utworów lub innych przedmiotów objętych ochroną. Przy określaniu formy, szczegółowych warunków i ewentualnej wysokości takiej godziwej rekompensaty należy uwzględnić okoliczności każdego przypadku. Przy ocenie tych okoliczności pomocnym kryterium byłaby potencjalna szkoda poniesiona przez podmiot praw autorskich w wyniku danej czynności. W przypadku gdy podmiot praw autorskich przyjął już zapłatę w innej formie, na przykład jako strona opłaty licencyjnej, specjalna lub oddzielna zapłata może nie być należna. Wysokość godziwej rekompensaty musi uwzględniać stopień wykorzystania zabezpieczeń technicznych przewidzianych w niniejszej dyrektywie. W niektórych przypadkach, gdy szkoda poniesiona przez podmiot praw autorskich jest niewielka, może nie powstać żadne zobowiązanie do zapłaty”.

Jak już nadmieniono, pojęcie „godziwej rekompensaty” zostało zdefiniowane w treści art. 5 ust. 2 lit. b dyrektywy 2001/29/WE. W tej sprawie Trybunał podkreślił, aby godziwa rekompensata, o której mowa w dyrektywie, koniecznie była obliczana na podstawie kryterium szkody wyrządzonej twórcom chronionych utworów, będącej następstwem wprowadzenia wyjątku kopii na użytek prywatny. Jak wynika z wyroku TSUE w sprawie Padawan SL przeciwko SGAE, wymiar wypłacanej rekompensaty nie powinien być ustalany abstrakcyjnie, ale powinien mieć związek z rozmiarem szkody, której doznał uprawniony, lecz nie musi być bezpośrednio powiązany $z$ konkretnym aktem eksploatacji utworu.

\section{Ogólna charakterystyka roszczenia o zapłatę godziwej rekompensaty za korzystanie z utworów osieroconych (art. 35 (8) ust. 5 ustawy o prawie autorskim)}

\section{Podmioty uprawnione do dochodzenia roszczenia o zapłatę godziwej rekompensaty za korzystanie z utworów osieroconych}

Jako uprawnionych do dochodzenia omawianego roszczenia ustawa wskazuje te podmioty, które są uprawnione z tytułu autorskich praw majątkowych do utworów uznanych za osierocone w zakresie pól eksploatacji, jakimi są zwielokrotnianie, nadawanie oraz udostępnianie publiczne utworów w taki sposób, aby każdy mógł mieć do nich dostęp w miejscu i czasie przez siebie wybranym. Godziwa rekompensata będzie mogła być wypłacona tylko w przypadku odnalezienia uprawnione- 
go, który z prawa do jej otrzymania będzie chciał skorzystać18. Jak słusznie wskazał P.F. Piesiewicz, „legitymację procesową czynną w zakresie możliwości dochodzenia roszczenia o zapłatę "godziwej rekompensaty« uprawniony [...] uzyskuje w momencie wygaśnięcia statusu utworu osieroconego"19.

\section{Podmioty zobowiązane do zapłaty roszczenia o zapłatę godziwej rekompensaty za korzystanie z utworów osieroconych}

Jako podmioty zobowiązane do zapłaty omawianego roszczenia ustawodawca wskazuje te, które podjęły się aktów korzystania z utworów osieroconych w zakresie pól eksploatacji, jakimi były zwielokrotnianie, nadawanie oraz udostępnianie publiczne utworów w taki sposób, aby każdy mógł mieć do nich dostęp w miejscu i czasie przez siebie wybranym. Do zapłaty roszczenia zobowiązane mogą być jedynie podmioty uprawnione do korzystania $\mathrm{z}$ dzieł osieroconych w ramach dozwolonego użytku (podmioty wymienione w art. $35^{5}$ ust. 2 ustawy o prawie autorskim), czyli: archiwa, instytucje oświatowe, uczelnie, instytuty badawcze prowadzące działalność, o której mowa w art. 2 ust. 3 ustawy z dnia 30 kwietnia 2010 r. o instytutach badawczych, instytuty naukowe Polskiej Akademii Nauk prowadzące działalność, o której mowa w art. 50 ust. 4 ustawy z dnia 30 kwietnia 2010 r. o Polskiej Akademii Nauk, biblioteki i muzea, a także instytucje kultury, których statutowym zadaniem jest gromadzenie, ochrona i upowszechnianie zbiorów dziedzictwa filmowego lub fonograficznego, oraz publiczne organizacje radiowe i telewizyjne. „Samo wymienienie podmiotów w art. $35^{5}$ ust. 2 ustawy o prawie autorskim nie przesądza jeszcze o tym, że podmiot taki automatycznie uzyskuje legitymację procesową bierną [...]. Konieczne jest, aby podmiot został zarejestrowany jako upoważniony do korzystania $z$ utworu osieroconego"20.

Przepisy polskiego prawa autorskiego dotyczące utworów osieroconych zostały ukształtowane w taki sposób, że w praktyce gdy tylko jedna z instytucji dokona starannych poszukiwań i doprowadzi do uznania danego utworu za utwór osierocony oraz dokona jego rejestracji w bazie utworów osieroconych, o której mowa $\mathrm{w}$ art. $35^{7}$ ust. 1 ustawy o prawie autorskim, także inne uprawnione podmioty wymienione w art. $35^{5}$ ust. 2 tej ustawy będą mogły legalnie rozpocząć eksploatację

18 Rządowy projekt ustawy nowelizującej ustawę o prawie autorskim i prawach pokrewnych oraz ustawy o grach hazardowych z dnia 22 maja 2015 r., Druk nr 3449, Uzasadnienie, s. 71, https://www.sejm.gov. pl/sejm7.nsf/druk.xsp?nr=3449 [dostęp: 21.05 .2020 r.].

19 P.F. Piesiewicz, Godziwa rekompensata..., s. 39.

20 Tamże, s. 40. 
dzieła osieroconego. W konsekwencji po umieszczeniu utworu w rejestrze eksploatacja utworu osieroconego będzie mogła być prowadzona przez kilka podmiotów równocześnie. Spostrzeżenie to rodzi pytanie, czy art. $35^{8}$ ust. 5 ustawy o prawie autorskim daje podstawy do wystąpienia $\mathrm{z}$ roszczeniami o zapłatę godziwej rekompensaty tylko do pierwotnego podmiotu, który doprowadził do uznania dzieła za osierocone, czy też do wszystkich podmiotów, które podjęły akty eksploatacji utworu osieroconego? W mojej ocenie wykładnia gramatyczna art. $35^{8}$ ust. 5 ustawy o prawie autorskim pozwala twierdzić, że z roszczeniem tym można wystąpić przeciwko każdej uprawnionej instytucji, która podjęła eksploatację dzieła osieroconego. Jak słusznie stwierdziła M. Nowotnik-Zajączkowska, „Za okres korzystania $\mathrm{z}$ utworu osieroconego uprawnionemu należy się jedynie godziwa rekompensata, ale od wszystkich podmiotów beneficjentów korzystających z utworu”. ${ }^{21}$

\section{Roszczenie o zapłatę godziwej rekompensaty za korzystanie z utworów osieroconych a prawo do wynagrodzenia}

Jednym z podstawowych uprawnień wchodzących w zakres pojęcia autorskich praw majątkowych jest prawo twórcy do wynagrodzenia za korzystanie z utworu. Konstrukcja prawna dotycząca eksploatacji utworów osieroconych ukształtowana została w taki sposób, że umożliwia określonym podmiotom na warunkach szczegółowo opisanych w ustawie korzystać z utworów osieroconych bez obowiązku zapłaty podmiotom uprawnionym rekompensaty za korzystanie $\mathrm{z}$ utworów, do chwili gdy podmiot uprawniony nie zostanie odnaleziony i nie zakwestionuje tego rodzaju eksploatacji. Jak więc można wywnioskować, podstawową funkcją omawianego roszczenia $\mathrm{z}$ art. $35^{8}$ ust. 5 ustawy o prawie autorskim jest zrekompensowanie (czyli naprawienie) uszczerbku w sferze majątkowej podmiotu uprawnionego, wynikającego $\mathrm{z}$ faktu, że eksploatacja dzieła osieroconego odbywała się w warunkach braku zapłaty autorskiego prawa do wynagrodzenia, o którym mowa w art. 17 ustawy o prawie autorskim. Nie powinno budzić wątpliwości, że mimo iż eksploatacja dzieł osieroconych odbywa się bez zgody uprawnionego oraz bez obowiązku zapłaty wynagrodzenia autorskiego, nie będą miały tu zastosowania roszczenia $\mathrm{z}$ art. 79 ustawy o prawie autorskim. $\mathrm{Z}$ treści tego przepisu wyni-

21 M. Nowotnik-Zajączkowska, Komentarz do art. 35(8) ustawy o prawie autorskim i prawach pokrewnych, w: Prawo autorskie i prawa pokrewne. Komentarz, red. W. Machała, R.M. Sarbiński, 2019 [wyd. el. LEX], teza nr 7. 
ka, że opisanych w nim roszczeń można dochodzić w sytuacji, gdy „prawa majątkowe zostały naruszone", czyli gdy korzystanie z utworu odbywało się w sposób bezprawny ${ }^{22}$. Korzystanie $z$ utworów osieroconych zgodnie z regulacjami ustawy o prawie autorskim (art. $35^{5}-35^{9}$ ) z całą pewnością wyłączy bezprawność naruszenia i uniemożliwi podnoszenie roszczeń opisanych w art. 79 tej ustawy. Jak wskazano w literaturze, „korzystanie z utworu uznanego za osierocony nie jest bezprawne do momentu ujawnienia się uprawnionego, chyba że poszukiwania były prowadzone niestarannie lub w złej wierze" ${ }^{23}$. Podnoszenie roszczeń z art. 79 ustawy o prawie autorskim możliwe byłoby jedynie w sytuacji, w której mimo utraty statusu utworu osieroconego któryś z podmiotów uprzednio uprawnionych kontynuowałby korzystanie $\mathrm{z}$ utworu osieroconego bez zgody uprawnionego. Roszczenie $\mathrm{z}$ art. 79 ustawy o prawie autorskim mogłoby obejmować jedynie okres po wygaśnięciu statusu utworu osieroconego ${ }^{24}$. Jak podniesiono w uzasadnieniu rządowego projektu ustawy nowelizującej prawo autorskie: „Podmiot beneficjent ponosi odpowiedzialność za ewentualne naruszenie autorskich praw majątkowych do utworu niesłusznie uznanego za osierocony, z którego korzystano na podstawie poszukiwań przeprowadzonych niestarannie albo w złej wierze"25.

Rozważając, jakie elementy składają się na treść roszczenia o zapłatę godziwej rekompensaty za korzystanie z utworów osieroconych, w pierwszej kolejności należy zastanowić się nad tym, czy rozmiar tego roszczenia nie powinien pokrywać się z wynagrodzeniem, które twórca utworu uznanego za osierocony uzyskałby, gdyby doszło do zawarcia z nim umowy o eksploatację utworu. W kontekście tego zagadnienia rodzi się pytanie dotyczące tego, czy twórcy utworu uznanego za osierocony przysługuje prawo do wynagrodzenia za korzystanie z jego utworu, jeśli eksploatacja dzieła osieroconego odbywa się na warunkach opisanych w art. $35^{5}-35^{9}$ ustawy o prawie autorskim?

Jest sprawą oczywistą, że autorskie prawo do wynagrodzenia jest następstwem istnienia autorskich praw majątkowych. Ustawową definicję autorskich praw majątkowych wyraża art. 17 ustawy, podając, że składają się na nie: prawo do wynagrodzenia, prawo do korzystania z utworu i prawo do rozporządzania

22 Zob. wyrok SN z dnia 25 listopada 1999 r., II CKN 573/98, LEX nr 145313; M. Czajkowska-Dąbrowska, Przeglad orzecznictwa z zakresu prawa autorskiego (zagadnienia wybrane), Glosa 2005, nr 2, s. 67.

23 M. Nowotnik-Zajączkowska, Komentarz do art. 35(8) ustawy o prawie autorskim..., teza nr 7; podobnie A. Michalak, Kierunki implementacji dyrektywy 2012/28/UE (dzieła osierocone) do prawa polskiego, Europejski Przegląd Sądowy 2013, nr 10, s. 28.

24 Podobnie M. Nowotnik-Zajączkowska, Komentarz do art. 35(8) ustawy o prawie autorskim..., teza nr 7.

25 Rządowy projekt ustawy nowelizującej ustawę o prawie autorskim i prawach pokrewnych oraz ustawy o grach hazardowych z dnia 22 maja 2015 r., Druk nr 3449, Uzasadnienie, s. 65-66. 
utworem. Majątkowe prawa autorskie mają charakter praw podmiotowych bezwzględnych, ich źródło oraz treść wyznacza wskazany przepis ustawy, są one skuteczne erga omnes, co oznacza, że prawo decydowania o każdej formie korzystania $\mathrm{z}$ utworu wyznacza uprawniony (twórca lub jego następca prawny) ${ }^{26}$. Wkroczenie w sferę opisanego wyżej prawa majątkowego, zastrzeżoną dla uprawnionego, powoduje powstanie roszczeń przewidzianych w art. 79 ustawy o prawie autorskim ${ }^{27}$.

$\mathrm{Z}$ treści art. 17 ustawy o prawie autorskim wynika, że prawo do wynagrodzenia przysługuje twórcy, chyba że przepis szczególny stanowi inaczej. W regulacjach o dozwolonym użytku mamy do czynienia właśnie z takim przepisem szczególnym, który wyłącza prawo do wynagrodzenia. Art. 34 ustawy o prawie autorskim stwierdza bowiem, że twórcy utworu eksploatowanego w ramach dozwolonego użytku wynagrodzenie nie przysługuje, chyba że ustawa stanowi inaczej. W art. $35^{5}$ ust. 7 ustawy o prawie autorskim czytamy, że do utworów osieroconych stosuje się tylko zd. pierwsze i drugie art. 34 ustawy o prawie autorskim. Należy zatem przyjąć, że do utworów osieroconych nie stosuje się zdania mówiącego o tym, że z tytułu korzystania $w$ ramach dozwolonego użytku wynagrodzenie nie przysługuje. Podsumowując tę część rozważań, trzeba stwierdzić, że uprawnionemu z tytułu autorskich praw majątkowych, którego utwór osierocony podlegał eksploatacji, wynagrodzenie $\mathrm{w}$ rozumieniu art. 17 ustawy o prawie autorskim będzie przysługiwać, ale, jak zostało to już zauważone, nie można dochodzić jego zapłaty na podstawie art. 79 ustawy o prawie autorskim.

Analizując treść prawa do wynagrodzenia należnego uprawnionemu, którego utwór był eksploatowany jako utwór osierocony, należy zauważyć, że wynagrodzenie to nie będzie stanowiło konsekwencji zawartej umowy, ale następstwo zrealizowania przesłanek stanu faktycznego opisanego w ustawie. W piśmiennictwie istnieje zgodność co do tego, że prawo do wynagrodzenia autorskiego może powstać także wtedy, gdy nie będzie konsekwencją rozporządzenia przez uprawnionego swym majątkowym prawem autorskim, lecz będzie istniało ze względu na treść konkretnego przepisu ustawy pozwalającego uprawnionemu (twórcy) domagać się wypłaty wynagrodzenia w określonych okolicznościach. Jako przykłady tego rodzaju sytuacji, gdy prawo do wynagrodzenia powstaje niezależnie od stosunków umownych, wskazać można na przypadki opisane w następujących

26 E. Traple, w: System Prawa Prywatnego, t. 13. Prawo autorskie, red. J. Barta, wyd. 2, Warszawa 2007, s. 122; por. także taż, w: System Prawa Prywatnego, t. 13, wyd. 3, s. 149-162; zob. M. Pyziak-Szafnicka, w: System Prawa Prywatnego, t. 1. Prawo cywilne - część ogólna, red. M. Safjan, Warszawa 2007, s. 734. 
przepisach ustawy: art. 19, art. 20, art. 21, art. 25 ust. 2, art. 70 ust. 3 ustawy o prawie autorskim ${ }^{28}$.

Jedynym więc przepisem w polskim porządku prawnym, umożliwiającym realizację przysługującemu twórcy (uprawnionemu) prawa do wynagrodzenia za eksploatację dzieła osieroconego będzie opisywany tu art. $35^{8}$ ust. 5 ustawy o prawie autorskim, umożliwiający podnoszenie roszczenia o zapłatę godziwej rekompensaty za korzystanie z utworów osieroconych w takim znaczeniu, że wynagrodzenie autorskie powinno stać się jednym z kluczowych składników tego roszczenia, który nie powinien być nigdy pominięty, mimo tego, że nie jest wyraźnie wymieniony w treści art. $35^{8}$ ust. 5 ustawy o prawie autorskim. Z drugiej strony omawiane roszczenie nie może być utożsamiane z prawem twórcy do wynagrodzenia. Jak wskazano w piśmiennictwie, „zgodnie z zasadą racjonalnego ustawodawcy należy przyjąć, że pojęcie godziwej rekompensaty ma inne znaczenie niż wynagrodzenie"29. Wynagrodzenie zatem powinno stać się jedynie jednym z obligatoryjnych elementów składowych godziwej rekompensaty.

\section{Kryteria oceny rozmiarów roszczenia o zapłatę godziwej rekompensaty z tytułu eksploatacji dzieła osieroconego}

Przypomnijmy, że z zgodnie z pkt 18 preambuły dyrektywy 2012/28/UE „państwa członkowskie powinny mieć swobodę określenia okoliczności, w których ma miejsce wypłata takiej rekompensaty, w tym terminu zapłaty należnej kwoty. Do celów określania możliwego poziomu godziwej rekompensaty trzeba należycie uwzględnić, między innymi, cele państw członkowskich związane z promowaniem kultury, niekomercyjny charakter korzystania z utworu przez przedmiotowe organizacje, którego celem jest realizacja zadań leżących w interesie publicznym, takich jak promowanie nauki i rozpowszechnianie kultury, oraz ewentualne szkody wyrządzone podmiotom uprawnionym".

Formułując treść art. $35^{8}$ ust. 5 ustawy o prawie autorskim, ustawodawca wskazał, że „wysokość rekompensaty uwzględnia charakter i zakres korzystania z tego utworu, wysokość przychodów uzyskanych na podstawie art. $35^{5}$ ust. 3 zdanie drugie oraz szkodę, jaka została wyrządzona uprawnionemu w związku z tym

28 Szerzej na ten temat zob. D. Sokołowska, Prawo twórcy do wynagrodzenia w prawie autorskim, Poznań 2013, s. 23 i n.

29 M. Nowotnik-Zajączkowska, Komentarz do art. 35(8) ustawy o prawie autorskim..., teza $\mathrm{nr} 10$. 
korzystaniem”. Z wykładni gramatycznej treści tego przepisu wynika, że sąd ustalając wysokość omawianego roszczenia, obowiązany jest uwzględnić trzy elementy:

1) zakres korzystania $z$ utworu osieroconego;

2) wysokość przychodów uzyskanych na podstawie art. $35^{5}$ ust. $3 \mathrm{zd}$. drugie ustawy o prawie autorskim;

3) szkodę, jaka została wyrządzona uprawnionemu w związku z tym korzystaniem. W myśl art. $35^{8}$ ust. 5 ustawy o prawie autorskim rekompensata powinna uwzględniać m.in. wysokość szkody, jeśli takowa została wyrządzona eksploatacją dzieła osieroconego. Wydaje się, iż można stwierdzić, że eksploatacja utworu osieroconego zawsze spowoduje szkodę w znaczeniu lucrum cessans, której wysokość równa będzie kwocie wynagrodzenia, jakie uprawniony uzyskałby, gdyby podmiot chcący eksploatować utwór osierocony byłby zobowiązany mu zapłacić. Jak wskazał P.F. Piesiewicz, przepis art. $35^{8}$ ust. 5 ustawy o prawie autorskim nakazuje przyjęcie hipotetycznej sytuacji, że korzystanie $z$ utworu odbywałoby się bez uprawnienia i w związku z takim korzystaniem podmiot poniósłby szkodę w ustalonej kwocie ${ }^{30}$.

Zatem z wykładni przepisów wynika, że uprawnionemu do dzieła osieroconego przysługuje wynikające $\mathrm{z}$ art. 17 ustawy o prawie autorskim prawo do wynagrodzenia. W mojej opinii są podstawy by twierdzić, że to przysługujące uprawnionemu prawo do wynagrodzenia powinno stać się podstawą szacowania szkody w znaczeniu lucrum cessans i w tym kontekście stanowić powinno jeden z kluczowych składników roszczenia o godziwą rekompensatę. W praktyce kwota roszczenia o godziwą rekompensatę nie powinna być niższa niż kwota należnego uprawnionemu wynagrodzenia ${ }^{31}$.

Warto nadmienić, że gdyby ustawodawca w omawianym przepisie odwołał się jedynie do pojęcia rekompensaty utraconego wynagrodzenia autorskiego, wówczas narzuciłoby to sztywny obowiązek dokonywania odniesień jedynie do realiów rynkowych obrotu prawami autorskimi. Jak nie trudno zauważyć, w wielu przypadkach eksploatacja dzieł osieroconych dokonywana będzie przez publiczne instytucje kultury lub nauki w celach niekomercyjnych. Należy więc przypuszczać, że odwołane się ustawodawcy jedynie do pojęcia należnego wynagrodzenia skutkowałoby tym,

30 „Wypada zwrócić uwagę, że tak postawiona teza pozostaje w zgodzie ze wspomnianym wyrokiem Trybunału Sprawiedliwości UE z 21.10.2010 r.", zob. P.F. Piesiewicz, Godziwa rekompensata..., s. 44.

31 S. Stanisławska-Kloc słusznie zauważyła, że przy określeniu wynagrodzenia w stosunku do fotografii warto stosować stawki przyjęte w tabeli Związku Polskich Artystów Fotografików - http://zpaf.pl/prawa-autorskie/tabele-minimalnych-wynagrodzen, a w odniesieniu do utworów plastycznych - tabele stawek Związku Polskich Artystów Plastyków - http://www.zpap.pl/zpap/index.php?option=com_co ntent\&vwiem $=$ article\&id=99\&Itemid=106\&lang=pl; S. Stanisławska-Kloc, w: Prawo autorskie i prawa pokrewne. Komentarz, red. D. Flisak, 2015 [wyd. el. LEX], s. 535, 537. 
że uprawniony w większości przypadków byłby pozbawiony możliwości uzyskania korzyści majątkowych wyższych niż znikome. Ponadto precyzyjne obliczenie wartości należnego wynagrodzenia z tytułu eksploatacji dzieła osieroconego mogłoby być bardzo utrudnione lub wręcz niemożliwe.

Kontekst, w jakim zostało użyte pojęcie "godziwej rekompensaty” w przepisach dyrektywy 2012/28/UE dotyczącej dzieł osieroconych (podobnie jak w treści dyrektywy 2001/29/WE), pozwala twierdzić, że prawodawca europejski, a za nim ustawodawca polski, posługując się tym pojęciem, chciał dać wyraz temu, że chodzi o ustalenie świadczenia, którego wysokości nie można precyzyjne ustalić, a jedynie miarkować, mając na uwadze pewne kluczowe czynniki (wartość doznanej szkody, wymiar i charakter korzystania z utworu). Zgodnie z wyrokiem TSUE w sprawie Padawan SL przeciwko SGAE, dotyczącym interpretacji pojęcia „godziwej rekompensaty" zawartego w przepisach dyrektywy 2001/29/WE (dotyczącej reprografii), który jak wskazano jest aktualny także przy interpretacji pojęcia „godziwej rekompensaty" z dyrektywy 2012/28/UE (dotyczącej utworów osieroconych) oraz art. $35^{8}$ ust. 5 ustawy o prawie autorskim, do wypłaty godziwej rekompensaty nie powinno być wymagane wykazanie przez uprawnionego, że doznał konkretnej szkody, która pozostaje w adekwatnym związku przyczynowym z działaniem podmiotu eksploatującego utwór. Każdy bowiem akt korzystania z dzieła osieroconego bez zgody uprawnionego daje podstawy do domagania się wypłaty godziwej rekompensaty, a rozmiar ewentualnej szkody powinien być jedynie czynnikiem pozwalającym ustalić wymiar należnego świadczenia, a nie czynnikiem warunkującym zasadność takiego roszczenia. Interpretacja art. $35^{8}$ ust. 5 ustawy o prawie autorskim powinna zatem uwzględniać szczególne cechy pojęcia „godziwej rekompensaty", jakie zostały ukształtowane w orzecznictwie TSUE w sprawie Padawan SL przeciwko SGAE. Roszczenie o zapłatę godziwej rekompensaty aktualizuje się co do zasady, gdy uprawniony z tytułu praw autorskich do dzieła osieroconego wykaże fakt korzystania $z$ jego utworu w ramach konstrukcji dzieła osieroconego. Wykazanie innych wymienionych w treści omawianego przepisu przesłanek, jak rozmiar szkody, zakres użytku itp. zgodnie z rozkładem ciężaru dowodu powinno oczywiście obciążać powoda, jednak wykazanie tych okoliczności nie powinno mieć wpływu na zasadność roszczenia jako takiego, ale jedynie na wysokość dochodzonego roszczenia.

Ustalając wysokość godziwej rekompensaty, nie można zapominać, że eksploatacja dzieł osieroconych dotyczy zazwyczaj utworów istotnych dla dziedzictwa kulturowego. Odwołanie ustawodawcy do pojęcia „godziwej rekompensaty" daje uprawnionemu podstawę do domagania się wyższej kwoty pieniężnej niż kwota odpowiadająca wartości wynagrodzenia lub odszkodowania związanego 
z eksploatacją utworu ${ }^{32}$. Z treści analizowanego przepisu wynika, że godziwa rekompensata powinna uwzględniać także charakter oraz zakres korzystania $z$ utworu osieroconego. Te kryteria pozwalają wziąć pod uwagę aspekty pozaekonomiczne korzystania, jak np. jego znaczenie dla kultury czy wszelkiego rodzaju inne pozaekonomiczne korzyści, które uzyskało społeczeństwo, obcując z utworem (jego rolę kulturotwórczą, patriotyczną, historyczną, poznawczą, edukacyjną, naukową itp.). Przytoczone tu argumenty potwierdza lektura pkt 18 preambuły dyrektywy 2012/28/UE, gdzie stwierdzono, że do celów określenia poziomu godziwej rekompensaty trzeba należycie uwzględnić m.in. cele państw członkowskich związane z promowaniem kultury, niekomercyjny charakter korzystania $\mathrm{z}$ utworu przez przedmiotowe organizacje, którego celem jest realizacja zadań leżących w interesie publicznym, takich jak promowanie nauki i rozpowszechnianie kultury, oraz ewentualne szkody wyrządzone podmiotom uprawnionym.

Dodać trzeba, że przesłanka „zakresu korzystania z utworów” użyta w art. $35^{8}$ ust. 5 ustawy o prawie autorskim funkcjonowała w treści polskiej ustawy o prawie autorskim i prawach pokrewnych w treści obecnie już nieobowiązującego art. $110^{33}$. W piśmiennictwie wskazywano, że przepis ten miał charakter swoistej klauzuli generalnej, wyznaczającej ogólne kryteria, jakimi powinny kierować się organizacje zbiorowego zarządu przy podejmowaniu rozstrzygnięć dotyczących wynagrodzenia ustalanego w ramach sprawowania zbiorowego zarządu.

\section{Zakończenie}

Z przeprowadzonych rozważań wynika, że zasadność roszczenia z art. $35^{8}$ ust. 5 ustawy o prawie autorskim nie powinna być uzależniona od faktu wykazania przez powoda konkretnej szkody, którą wywołało działanie podmiotu eksploatującego

32 Por. odmiennie M. Nowotnik-Zajączkowska, Komentarz do art. 35(8) ustawy o prawie autorskim..., teza $\mathrm{nr}$ 10. Autorka stoi na stanowisku, że wynagrodzenie ustalone w tabelach minimalnych wynagrodzeń autorskich (w tabeli Związku Polskich Artystów Fotografików oraz dla utworów plastycznych w tabelach stawek Związku Polskich Artystów Plastyków) może stanowić punkt odniesienia dla określenia wysokości godziwej rekompensaty i stanowić maksymalną kwotę stanowiącą godziwą rekompensatę.

33 Art. 110 ustawy Prawo autorskie stanowił: „wysokość wynagrodzeń dochodzonych w zakresie zbiorowego zarządzania przez organizacje zbiorowego zarządzania powinna uwzględniać wysokość wpływów osiąganych z korzystania z utworów i przedmiotów praw pokrewnych, a także charakter i zakres korzystania z tych utworów i przedmiotów praw pokrewnych". Przepis uchylony ustawą z dnia 15 czerwca 2018 r. o zbiorowym zarządzaniu prawami autorskimi i prawami pokrewnymi (Dz. U. z 2018 r. poz. 1293) z dniem 19 lipca 2018 r. 
utwór osierocony, czy też od istnienia związku przyczynowego między zachowaniem podmiotu eksploatującego utwór a szkodą. Zaistnienie takiej szkody może jedynie mieć wpływ na wymiar opisywanego roszczenia, a nie na jego zasadność. Wykazanie przez uprawnionego szkody może tylko spowodować zwiększenie należnej mu kwoty rekompensaty. Jak się wydaje, rozmiar szkody, który w tego rodzaju sytuacjach będzie najprościej wykazać, dotyczył będzie szkody w znaczeniu lucrum cessans i równy będzie kwocie wynagrodzenia, której uprawniony nie uzyskał od podmiotów eksploatujących jego utwór w ramach konstrukcji dzieł osieroconych. Można więc stwierdzić, że dolne granice opisywanego roszczenia o zapłatę godziwej rekompensaty z art. $35^{8}$ ust. 5 ustawy o prawie autorskim zawsze wyznaczać będzie kwota odszkodowania równa kwocie należnego wynagrodzenia za korzystanie z utworu. Zasądzenie wyższych kwot niż te minimalne wartości, wynikające choćby z chęci zrównoważenia ewentualnego wynagrodzenia, które uzyskałby uprawniony gdyby zawarto z nim umowę, pozostawione zostało uznaniu sądu i warunkowane jest m.in. zakresem korzystania $\mathrm{z}$ utworu oraz wysokością przychodów uzyskanych na podstawie art. $35^{5}$ ust. 3 zd. drugie ustawy o prawie autorskim.

W związku z powyższym można zaryzykować twierdzenie, że pojęcie „godziwej rekompensaty” to swego rodzaju klauzula generalna odnosząca się do ustalania wysokości zasądzanego roszczenia, gdzie jedynie dolna granica została ograniczona odniesieniem do szkody równej w praktyce co najmniej wartości utraconego wynagrodzenia autorskiego. W opisywanym pojęciu można się dopatrywać odwołań do ocen pozaprawnych o charakterze aksjologicznym. Pojęcia „godziwy”, „niegodziwy" to terminy wartościujące z zakresu etyki, godziwy to innymi słowy moralny. Sędzia stosując omawiany przepis, powinien mieć więc na uwadze, by zasądzone świadczenie w oczach rozsądnie myślących obywateli było godziwe, czyli moralne, godne i dobre. W moim mniemaniu takim właśnie owo świadczenie będzie, jeśli sąd obliczając jego wartość, uwzględni utracone należne twórcy wynagrodzenie oraz inne pozaekonomiczne korzyści, jakie przyniosło społeczeństwu korzystanie z określonego utworu osieroconego.

\section{Bibliografia}

Barta J., Markiewicz R., Prawo autorskie i prawa pokrewne. Przepisy z wprowadzeniem, Warszawa 2017.

Błeszyński J., Glosa do postanowienia SA z dnia 24 lutego 2009 r., I ACa 99/09, Przegląd Ustawodawstwa Gospodarczego 2009, nr 7. 
Błeszyński J., Podział opłat od producentów i importerów urządzeń kopiujących, Przegląd Ustawodawstwa Gospodarczego 2001, nr 12.

Czajkowska-Dąbrowska M., Opłaty reprograficzne - osobliwości konstrukcji, dylematy praktyki, w: Studia i Analizy Sądu Najwyższego t. 4, red. K. Ślebzak, Warszawa 2012.

Czajkowska-Dąbrowska M., Przegląd orzecznictwa z zakresu prawa autorskiego (zagadnienia wybrane), Glosa 2005, nr 2.

Gołda-Sobczak M., Opłaty reprograficzne w polskim prawie autorskim jako forma zarzadzania kultura, Zarządzanie w Kulturze 2014, t. 15, nr 2.

Kępiński M., Kleban B., w: System Prawa Prywatnego, t. 13. Prawo autorskie, red. J. Barta, wyd. 3, Warszawa 2013.

Michalak A., Kierunki implementacji dyrektywy 2012/28/UE (dzieła osierocone) do prawa polskiego, Europejski Przegląd Sądowy 2013, nr 10.

Niewęgłowski A., Dyrektywa w sprawie dzieł osieroconych i jej znaczenie dla polskiego prawa autorskiego, Transformacje Prawa Prywatnego 2013, nr 3.

Nowotnik-Zajączkowska M., Komentarz do art. 35(8) ustawy o prawie autorskim i prawach pokrewnych, w: Prawo autorskie i prawa pokrewne. Komentarz, red. W. Machała, R.M. Sarbiński, 2019 [wyd. el. LEX].

Piesiewicz P.F., Godziwa rekompensata i jej dochodzenie w odniesieniu do dzieł osieroconych (art. 358 ust. 5 ustawy o prawie autorskim i prawach pokrewnych), Zeszyty Naukowe Uniwersytetu Jagiellońskiego 2018, nr 3.

Pyziak-Szafnicka M., w: System Prawa Prywatnego, t. 1. Prawo cywilne - część ogólna, red. M. Safjan, Warszawa 2007.

Sieńczyło-Chlabicz J., Nabycie i utrata statusu utworu osieroconego - uwagi de lege lata $i$ de lege ferenda, w: Experientia docet. Księga jubileuszowa ofiarowana Pani Profesor Elżbiecie Traple, red. P. Kostański, P. Podrecki, T. Targosz, Warszawa 2017.

Sokołowska D., Opłaty reprograficzne, Warszawa 2014.

Sokołowska D., Prawo twórcy do wynagrodzenia w prawie autorskim, Poznań 2013.

Stanisławska-Kloc S., Utwory „osierocone”, Zeszyty Naukowe Uniwersytetu Jagiellońskiego. Prace z Prawa Własności Intelektualnej 2007, nr 4.

Stanisławska-Kloc S., w: Prawo autorskie i prawa pokrewne. Komentarz, red. D. Flisak, 2015 [wyd. el. LEX].

Szczotka J., w: Prawo autorskie i prawa pokrewne. Zarys wykładu, red. M. Poźniak-Niedzielska, J. Szczotka, M. Mozgawa, Bydgoszcz 2006.

Traple E., w: System Prawa Prywatnego, t. 13. Prawo autorskie, red. J. Barta, wyd. 2, Warszawa 2007.

Vetulani A., Dzieła osierocone - w poszukiwaniu europejskiego rozwiązania, Zeszyty Naukowe Uniwersytetu Jagiellońskiego. Prace z Prawa Własności Intelektualnej 2009, nr 1. 
